\title{
Warning-Television viewing may harm your child's health: Parent perceptions of early childhood viewing habits
}

\author{
Susanne Garvis \\ Donna Pendergast \\ Griffith University
}

IN 2009, THE AUSTRALIAN Government introduced the Get Up and Grow (Commonwealth Government, 2009) guidelines for healthy eating and exercise in early childhood as one element of a range of initiatives aiming to curb childhood obesity, a problem affecting an increasing proportion of Australia children. Included in the policy recommendations are banning children from watching television until they turn two; and limiting viewing to one hour a day for those aged between two and five years. These recommendations represent a considerable shift in the reported average viewing practices for these age groups, providing an opportunity for community comment.

In 2009, the article 'Childhood policy straight out of fantasyland' (Edgar, 2009) appeared on the Sydney Morning Herald website. The article was a critique of the Get Up and Grow recommendations. Most articles on the $S M H$ website have an anonymous blog post attached where readers can post their comments. Data was collected from this blog, and responses where the identity of the respondent as a parent was either implicitly or explicitly stated were used and the text analysed. Six themes were generated from the data: television as an educator; television as a babysitter; television as a motivator for increasing physical exercise; policy as a challenge to parental rights; age appropriateness; and viewing standards. The responses provide insights into children's viewing habits and glimpses of the way television is used in the family household. Findings also reveal that parents accept that television programs labelled as 'educational' are a positive influence on learning for their child, and do not scrutinise the content beyond this assumption.

\section{Introduction}

Since the advent of television, concern has been raised about viewing by young children. In recent years these concerns have extended to the television viewing habits of children under two, with reports of high levels of viewing and a focus on the development of this age group as a consumer market. In some parts of the world, television has been subjected to legislative controls in response to research that reports a correlation between delayed language development and television viewing. For instance, in 2008 France's broadcast authority banned French channels from airing television programs aimed at children under the age of three years. In justifying this stance, the High Audiovisual Council of France (2008) argued that television viewing negatively impacts on the development of children under three and poses risks such as encouraging passivity; slow language acquisition; over-excitement; trouble with sleep and concentration; and dependence on screens. Subsequent to this initial action, regular French broadcast channels are now banned from airing programs for underthrees, and cable channels must include the following broadcast warning statement: 'Watching television can slow the development of children under 3, even when it involves channels aimed specifically at them' (High Audiovisual Council of France, 2008).

In 2009 the Australian Government introduced the Get Up and Grow (Commonwealth Government, 2009) guidelines for healthy eating and exercise in early childhood as an initiative to curb childhood obesity. Based on the growing research of television's impact on young children, two of the policy recommendations were (1) to ban children from watching television until they turn two; and (2) viewing from ages two to five should be limited to one hour a day. The restriction on screen viewing was directly linked to increased inactivity in childhood and poor food choices. This study was conducted within this context, and was particularly interested in exploring parental responses to the recommendations, along with their reported experiences of television viewing. 


\section{Young children's television viewing habits}

Young children's television viewing has received limited research attention in Australia. However, it is known that children start watching television soon after birth (Cupitt, 1998) and a considerable time each day is allocated to the activity. In 2007 the Australian Communication Authority released a report of children's television viewing patterns for 2006. Based on the average time spent viewing television for 2006, birth-14-year-olds spent an average of 142 minutes, or almost two-and-a-half hours per day, watching free-toair television (ACMA, 2007a, p. 5). Children aged birthfour years spent an average of 154 minutes (more than two-and-a-half hours) watching free-to-air television (ACMA, 2007a, p. 5). With subscription television, viewing was conservatively estimated as 44 minutes per day for the average four-month-old infant and averaging 194 minutes, or more than three hours, per day for the birth-four years age group (ACMA, 2007a).

It was reported that 'programs specifically made for children dominated the viewing habits of the $0-4$ age group', with ' 47 of the top 50 programs watched by the 0-4 years group in 2005 categorised as children's programs. All of these programs were broadcast on the $A B C^{\prime}$ (ACMA, 2007a, p. 7). The top five television programs viewed by children aged birth-four during 2006 were Bob the builder special—Bob snowed under; Ice Age (movie); Thomas and Friends; Rubbadubbers; and The Biggest Loser (ACMA, 2007a, p. 50). For five12-year-olds, the top five programs viewed in 2006 were 2006 Opening Ceremony for the Commonwealth Games; The Biggest Loser-Finale; Futurama (Episode 1); Big Brother Launch; and Futurama (Monday nights) (ACMA, 2007a, p. 53). It seems that children do not exclusively or even preferentially watch programs classified as children's programs.

Also in 2007, the Australian Communications and Media Authority (2007b) released the report Media and communications in Australian families. It reported on a national survey of 751 Australian families, including time-use diaries for 1003 children aged eight-17 years, along with a review of the academic research literature about the influences of communications and media. While not reporting on young children in the early years phase (birth-eight years), the study provides evidence of television viewing habits in families. Findings confirmed that watching television remained a daily activity for children aged eight-17 years, with children watching just under two hours of television per day (ACMA, 2007b, p. 3). Children also spent more time watching free-to-air television than on any other activity, with viewing time increasing as children get older (ACMA, 2007b, p. 4).

The amount of time the television is turned on may also contribute to increased viewing habits. In 2008, it was reported that around 30 per cent of children live in households that have television on all the time, appearing as background entertainment. In these households, television was used as a babysitter, even from earliest infancy (Edgar \& Edgar, 2008). The results also provide insight into parental monitoring of television content. Contrary to common assumptions, young children increasingly watch television on their own, without the presence of a parent or older sibling to regulate their experiences (RACP, 2004).

\section{Broadcasting standards}

Applying a universal level of quality and excellence for Australian children's television standards is complex. Assessing quality and excellence can be viewed as subjective, 'particularly if the grounds for judgement are not explicit' (Bazalgette \& Buckingham, 1995, p. 9). The Australian Broadcasting Tribunal has used regulation and standardisation to promote quality and excellence in children's programs, promoting broadcasting standards that are difficult to enact.

When television broadcasting began, programs were monitored without formal standards or regulations. In 1968, concerned with the lack of local children's programming, the Australian Broadcasting Control Board established a series of committees to advise on matters related to children's television (Aisbett, 2000, p. 7). Its successor, the Australian Broadcasting Tribunal, further engaged in the improvement of children's programs by developing the ' $\mathrm{C}$ ' standards for children programs and ' $P$ ' standard for preschool programs. Accordingly, for a program to be classified ' $C$ ' it must achieve the following criteria:

a. be made specifically for children or groups of children within the preschool or primary school age range

b. be entertaining

c. be well-produced, using sufficient resources to ensure a high standard of direction, editing, shooting, sound and other production elements

d. enhance a child's understanding and experience

e. be appropriate for Australian children.

Over the past 25 years, the broadcasting criteria have remained in place for children's programs. The Australian Broadcasting Tribunal refined these criteria further in 1991 by stating that they do not mean that ' $C$ ' programs have to be 'worthy' or 'education' (Aisbett, 2000, p. 95). No topic is considered taboo by scriptwriters, but great care is needed in the way such topics are handled. Violence or dangerous practice is not considered acceptable. Furthermore, role-modelling should reflect contemporary lifestyles. Keyes (2000) believes that, while the regulatory broadcasting framework has been beneficial for viewers and producers, it is inappropriate 
for today. She proposes that children's television standards must be adapted through reinvention and re-examination of the regulatory framework; in other words, a fresh look.

While acknowledging these standards, Young Media Australia (YMA, 2003), supported by the Commonwealth Department of Family and Community Services, argues that early childhood television programs should promote ideologies of social responsibility that promote play and discourage stereotyping. The YMA considers current broadcasting standards for children's programs inappropriate, as they fail to model appropriate human experience in order to broaden understanding. For example, inappropriate modelling occurs by preschool programs promoting stereotypical sets of behaviour for boys and girls (YMA, 2003, p. 2).

\section{What are the benefits of television viewing?}

According to the Media and communication in Australian families 2007 report (ACMA, 2007b, p. 12), 'children and families use electronic media and communication activities because they have clear benefits of entertainment, relaxation and education'. Parents involved in the study also suggested engagement with electronic media and communication encouraged learning about other cultures, seeing others' points of view, being inspirational and promoting creativity, as well as providing safety, security and social support (ACMA, 2007b).

Some evidence suggests that television programs with prosocial content (positive interactions between different groups of people) and educational content may have social and educational benefits. For example, The Future of Children report (Kirkorian, Wartella \& Anderson, 2008) suggests there is 'strong evidence that children older than two learn from educational media and there is moderate evidence that exposure to educational television during the preschool years is positively linked with various measures of academic achievement even ten years later'. However, the report suggests the reverse for children younger than two.

\section{What are the problems associated with television viewing?}

A growing body of evidence in early childhood education reveals a litany of possible detrimental effects resulting from a child's exposure to television. Recent research points to problems associated with, for example, violence, obesity, language development and stereotyping. It is argued that young children seeing violence on television leads to responses such as the desensitisation to the emotional effects of violence, a lack of empathy with victims of violence, an increased tendency to aggression, and the perception of the world as scary (RACP, 2004). According to Young Media Australia (2007), exposure to violent content increases the risk that children may develop a violent mental script that is likely to be gendered (male as the hero/perpetrator and female as the victim). Vulnerable children are typically male, younger than seven, living in violent homes and heavy consumers of media (Young Media Australia, 2007).

Research also demonstrates links between adiposity (higher fat content mass) in preschoolers and increased television viewing (Woseje et al., 2009). Preschoolers with the least fat content mass did not watch television. In an Australian study, 20 hours or more of television viewing per week doubled the risk of being overweight or obese compared with children who watched less or no television per week (Wake, Hesketh \& Waters, 2003).

Links between delayed language development and television viewing have also been found. A United States study found that young children aged two-48 months had language development delayed when the television was on (Christakis et al., 2009). During television viewing, adult interactions with the child also decreased. Adults spoke less to children, with fewer examples of turn-taking responses and vocalisations. Correlations between exposure to background television and delayed language development have also been found by Chonchaiya and Pruksananonda (2008). This research revealed that a child's attempt at toy play and family interaction were distracted and interfered with by the background television.

Research also reveals that children under two years learn vocabulary better from real-life experience than from equivalent video presentation (Kremer, Grela \& Lin, 2007). A similar study suggests that television models are less effective than live ones preserving discrimination of found speech sounds (phonemes) in young children (Kuhl, Tsao \& Liu, 2003).

The Australian Communication and Media Authority (2007b) has also raised concerns of stereotyped content within television programs. Distorted and stereotyped representations of gender (including body image) and ethnic/racial stereotypes have all been reported.

\section{Australian Government recommendations}

In 2009 the Commonwealth Government released the Get Up and Grow Report: Healthy eating and physical activity for early childhood (Commonwealth Government, 2009). The report provides general 'non-commercial, evidence-based information to early childhood education and care settings, to assist in developing healthy habits for children birth to five years'. The guide provides healthy eating and exercise 
prescriptions for babies and children aged up to five years, developed by experts at the Murdoch Children's Research Institute and the Royal Children's Hospital in Melbourne.

In respect of television viewing habits, links were acknowledged between hours spent watching television and child wellbeing. Subsequently, the report made two recommendations for young children's viewing habits, which have been previously mentioned as the basis for the research conducted and subsequently reported in this paper (2009, p. 4):

Recommendation 1: Children younger than two years of age should not spend any time watching television or using other electronic media (DVDs, computer and other electronic games).

Recommendation 2: For children two to five years of age, sitting and watching television and the use of other electronic media (DVDs, computer and other electronic games) should be limited to less than one hour per day.

How these recommendations are to be implemented by the Federal Government is unclear as they are currently under discussion by policy-makers.

\section{Purpose of the study}

This study analyses parent comments about the recommendations for children's television viewing habits in Australia. It aims to generate themes around the responses and provide current insights to the beliefs and values about these viewing habits.

\section{Research method}

In 2009, the article 'Childhood policy straight out of fantasyland' (Edgar, 2009) appeared on the Sydney Morning Herald website. The article was a critique of the Get Up and Grow (Commonwealth Government, 2009) recommendations suggested by Australian policy-makers as part of an anti-obesity drive.

Most articles on the SMH website have a blog attached where readers can post their comments. This particular forum recorded 23 posts from anonymous readers. Respondents were a self-selecting, convenience sample. On average, most readers wrote three to four sentences. All posts were downloaded and screened for use in this study. All were considered suitable for inclusion as they were either explicitly or implicitly presented by 'parents'. Next, an adapted version of Cavana, Delahaye and Sekaran's (2003) 15 stages of content analysis (based within the constant comparative method) was used as a guide to identify key themes and meanings in the data. This process allowed newly identified themes to be compared with previously identified themes to ensure that the new theme added more understanding about the phenomenon under investigation. Themes were located with frequency counts, with some themes entering two categories. Coding for manifest content (Wallen \& Fraenkel, 2001) was used, which means that what was directly written in the online blog, as opposed to latent content which is implied, was used for the content analysis.

\section{Findings}

The content analysis resulted in the generation of six main themes: television as an educator; television as a babysitter; television as a motivator for increasing physical exercise; policy as a challenge to parental rights; age-appropriateness; and viewing standards. The frequency with which each theme was reported is presented in Figure 1. Each theme is discussed following the figure.

Figure 1: Frequency of occurrence of the six themes, as percentage

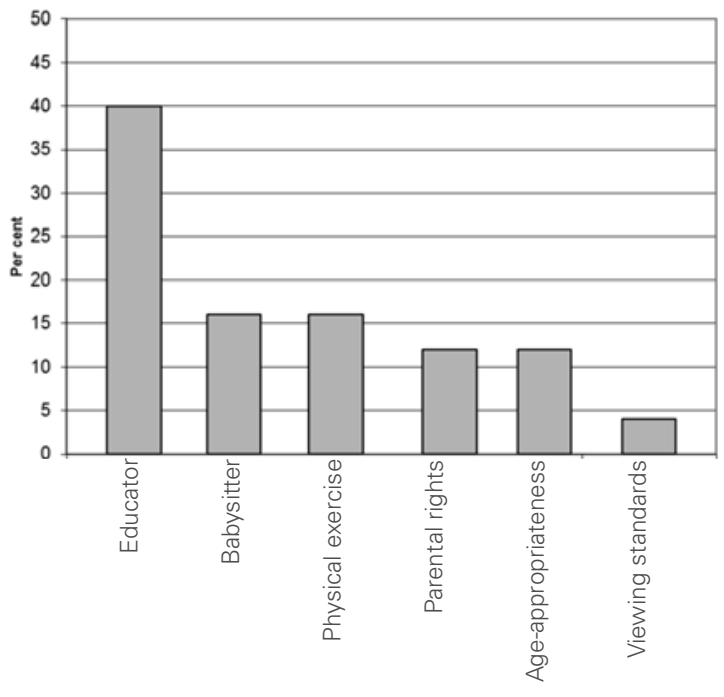

Television as an educator

The most frequent theme to emerge was the role of television as an educator (40\%). Respondents talked about the value of exposing their children to educational programs such as Dora the Explorer, Baby Einstein and Number Jacks. Typical comments included:

[M]y bub is four months old and to keep variety through the day, I allow him to watch most days a 'Baby Einstein' DVD which are 20 minutes long. They are educational with colours, music, animals, numbers etc. He loves them. Balance and moderation is the key! He gets a variety to do (Respondent 11). 
I think TV is fine. My nephew can speak Spanish from watching Dora and his parents encourage it (Respondent 16).

Interestingly, parents did not suggest how judgements were made about the educational value. They appeared to assume that, since television programs were labelled 'educational', they must be so. Parents considered that programs labelled 'educational' helped prepare students for school, as reflected in the following comment:

[T]hese days there are a plethora of educational shows for tots. My children have been exposed to classical music, counting, pre-readings, fitness, different cultures/languages, social skills etc. through TV. What they watch is designed to reinforce what they are learning in the real world and prepare them for school (Respondent 4).

\section{Television as a babysitter}

A smaller number of respondents (16\%) suggested that television was a babysitter for children. For some, it was used daily to enable carers to do other things. The following comments indicate this:

[T]hat 10 minutes while a child watches television may be what keeps Mum sane and an opportunity to go to the loo! (Respondent 8).

I have two ACTIVE boys aged 15 months and 2 and a half, and they love to watch ABC Kids Shows! It's a life saver (lets me get some housework done!) (Respondent 6).

Reportedly, young children sometimes share the viewing habits of their parents, no doubt because of their limited influence on program selection. As one respondent commented:

[M]y son is 5 months old and I sit him in front of the TV, but he isn't watching it, he is looking at the colours and trying to focus on the picture. He watches (looks at) Mel and Kochie every morning (Respondent 3).

(Mel and Kochie are the names of the hosts of a morning program.)

\section{Television as a motivator to increase physical exercise}

Physical exercise also emerged as a key theme in respondents' comments (16\%). Some said television was important for encouraging physical exercise among children. This perception is directly opposite to the intentions of the Get Up and Grow guidelines (2009) to target childhood obesity. Comments included:
[A]s far as encouraging inactivity, have these people watched toddlers and littlies watching Hi Five and Wiggles? My toddler doesn't sit, he dances and jumps (Respondent 13).

[B]oth my 2 and 5 year old love watching shows that have music and movement in it. I love watching my 2 year old trying to do some of the dance moves (Respondent 15).

$[H]$ e is nearly two and follows actions so isn't this part of physical activity if they are trying to copy dance moves even if it is for 15 minutes (Respondent 16).

\section{Policy as a challenge to parental rights}

Some respondents (12\%) said children's television viewing habits are the responsibility and right of the parent, not of the government. Parents suggested that the recommendation banning under-twos from watching television was a judgement on parenting styles. Parents considered their current techniques for children's viewing habits to be appropriate. Comments included:

[I]t should be up to the parent to decide on their child's TV habits (Respondent 1).

[SItop trying to take away our parental responsibilities that the majority of us do right (Respondent 7).

I am tired of so many judgements these days on what we should be doing. I feel constantly like I am failing my daughter with all the do's and don'ts. There is so much of it I don't want to listen to it anymore but it is always in the media. Recommendations are fine but judgements are just wrong! (Respondent 18).

\section{Age-appropriateness}

Age-appropriateness also emerged as a category in online comments (12\%). Respondents said television viewing by young children was acceptable providing it was age-appropriate. They appeared to make their own judgements about what was and what wasn't. Comments included:

I don't see anything wrong with young children watching TV at all as long as it is done in moderation and is age appropriate (Respondent 6).

I let my 18 month old daughter watch TV. I find it interesting to observe that she is already very discerning and only watches shows that are aimed at her age group. My aim as a parent is to help her become a critical viewer and not a passive observer (Respondent 10). 
I see no harm in letting kids watch TV as long as it is age appropriate and not too long each day (Respondent 23).

\section{Viewing standards}

One respondent commented on the challenge of enforcing the recommendations (4\%), likening it to the enforcement of audiences at movie theatres:

IW]hy is it that the government see fits to ban TV for children but I can go and see an MA15 rated movie and have five year olds in the cinema watching violence, sex, language, you name it and somehow this is perfectly acceptable because there is an irresponsible adult with them. Insane. (Respondent 2).

\section{Discussion and implications}

This study reports on anonymous comments on a blog attached to the newspaper article 'Childhood policy straight out of fantasyland' (Edgar, 2009), on the Sydney Morning Herald website. Responses where the identity of the respondent as a parent was either implicitly or explicitly stated were used and the text was analysed.

Findings reveal that the respondents, in this case 23 parents, articulated certain beliefs and values regarding the role of television in their children's lives. Many saw television as a form of supplementary education. Their comments revealed amazement at how children engaged with the content of television programs advertised as 'educational'. For example, a number of parents commented that their children could speak Spanish after watching Dora. However, it is unclear if these children actually understand and comprehend what they are memorising.

Parents' perceptions may also shed light on the values and beliefs of childcare workers. In many childcare centres throughout Australia, television programs are played daily to teach and engage children. Childcare workers' views about programs being educational are not known, and little is known about parents' perceptions towards their children watching television programs in childcare settings.

Parent respondents did not appear to critique the content of the early childhood television programs. Rather, parents commenting in the online blog assumed that early childhood programs provided educational experiences for their child. Greater research is therefore necessary into why parents accept programs labelled as 'educational' without critiquing the content. It is unclear how parents distinguish between programs that are 'educational' and those that are 'entertainment'.

It is also unclear from the limited data in this study if parents viewed television programs classed as educational together with their child. Some parents revealed that the television acted as a form of babysitting, providing an opportunity to get housework done. These statements suggest children may watch television by themselves, with parents assuming the content to be suitable for their child. This scenario, however, would provide little opportunity for discussion about ideas the child may have about the program they are viewing.

Parents also commented that, for some, television programs encouraged physical movement. They said their children danced when music programs were on television. Greater understanding of evolutionary musical research by parents is necessary. Babies appear to naturally synchronise (bounce to the beat of any type of music) at five months of age (Zentner \& Eerola, 2010). As the child hits the correct timing of the beat, they appear happier by smiling (Sentner \& Eerola, 2010). This is an involuntary movement that continues as the child develops. The child appears to have an internal beat that is triggered by the beat in musical television programs, so parents could turn the radio on instead of the television and young children would still be pre-dispositioned to move to the beat of the music.

The data analysis also provided some insight into possible hostility associated with the recommendations. Some parents commented that it was their responsibility to make decisions about their children's viewing habits. They felt capable of moderating their own child's viewing of television and allowing their child to view only age-appropriate programs. Yet the literature reveals, and this study confirms, that little is known about how parents decide what is age-appropriate viewing for their child. Research is needed to gain insights to how parents choose television viewing for their child. Logic may suggest that parents assume any children's program on television is suitable, based on the assumption that it is a program regulated by the Australian Broadcasting Standards. This pattern was evident in this study.

With the growing body of research showing links between delayed language development and television viewing for children under two years, research into changing parents' perceptions, values and beliefs regarding the role and value of television is necessary. Television is easily accessible by children, with television sets common in most homes. Children may also experience television in early childhood education settings, in public or at friends' houses. Given the growing number of television programs now being produced for infants and toddlers, it is important to understand the best way to provide quality educational experiences for children that encourage development. When is a program educational and when is a program simply entertaining to young children? What is the 
influence of television viewing on children in the early childhood classroom? Does watching television influence a young child's development towards school readiness?

This study has provided glimpses into parents' views about the value of television viewing and about the recommendations developed in the Get Up and Grow guidelines for healthy eating and exercise in early childhood. Two key themes that emerged from the data, that television is an educator and serves as a motivator to increase physical exercise, resonate strongly with the principles of the Get Up and Grow guidelines, actually setting up opposing views of the value of television to that implied in the recommendations. Hence, greater understanding of this area is needed, so we make a call for considerable research investment, especially as we seek to improve teaching and learning outcomes of Australian students, particularly in the domains of literacy and numeracy.

\section{References}

Aisbett, K. (2000). 20 Years of C - Children's television programs and regulation 1979-1999. Sydney: Australian Broadcasting Authority.

Australian Communication and Media Authority (ACMA) (2007a). Children's viewing patterns on commercial, free-toair and subscription television. Report analysing audience and ratings for 2001, 2005 and 2006 [Online]. Retrieved 28 January, 2010 from http://www.acma.gov.au/webwr/_assets/main/ lib310132/childrens_viewing_patterns.pdf.

Australian Communication and Media Authority (ACMA) (2007b). Media and communications in Australian families 2007. Report of the Media and Society Research Project 2007 [Online]. Retrieved 28 January, 2010 from http://www.acma. gov.au/webwr/_assets/main/lib101058/maciaf2007_overview. pdf.

Bazalgette, C., \& Buckingham, D. (1995). In front of the children: Screen entertainment and young audiences. London: British Film Institute.

Cavana, R. Y., Delahaye, B. L., \& Sekaran, U. (2001). Applied business research: Qualitative and quantitative methods. Brisbane, Queensland: John Wiley and Sons.

Chonchaiya, W., \& Pruksananonda, C. (2008). Television viewing associates with delayed language development. Acta Paediatrica, 97(7), 977-982.

Christakis, D., Gilkerson, J., Richards, J. A., Zimmerman, F. J., Garrison, M. M., Xu, D. et al. (2009). Audible television and decreased adult words, infant vocalizations, and conversational turns: a population-based study. Pediatrics \& Adolescent Medicine, 163(6), 554-558.

Commonwealth Government (2009). Get Up and Grow: Healthy eating and physical activity for early childhood [Online]. Retrieved 28 February, 2010 from http://www. earlychildhoodaustralia.org.au/pdf/doha/Family_FT.pdf.

Cupitt, M. (1998). Infants and television. Sydney: Australian Broadcasting Authority.

Edgar, D., \& Edgar, P. (2008, 30 September). Children and media forum. Melbourne: Victorian Curriculum and Assessment Authority.
Edgar, P. (2009, 19 October). Childhood policy straight out of fantasyland. The Sydney Morning Herald Retrieved 20 October, 2009 from http://www.smh.com.au/opinion/societyand-culture/childhood-policy-straight-out-of-fantasyland20091019-h38f.html

High Audiovisual Council of France (2008). Comment créer un service local non-hertzien [Online]. Retrieved 20 February, 2010 from http://www.csa.fr/infos/publications/publications_ television.php.

Keyes, W. (2000). Re-shaping policy: Children's television and cultural diversity broadcasting environment. International Forum of Researchers on Young People and the Media. (Unpublished).

Kirkorian, H. I., Wartella, E.A., \& Anderson, D. R. (2008). Media and young children's learning. The Future of Children, 18(1). Retrieved 6 January, 2010 from http://www.futureofchildren. org/futureofchildren/publications/journals/article/index.xml?jou rnalid $=32 \&$ articleid $=56 \&$ sectionid $=251$.

Kremer, M., Grela, B., \& Lin, K. (2007). Can toddlers learn vocabulary from television? An experimental approach, Media Psychology, 10(1), 41-63.

Kuhl, P. K., Tsao. F.-M., \& Liu, H.-M. (2003). Foreign-language experience in infancy: Effects of short-term exposure and social interaction on phonetic learning. Proceedings of the National Academy of Sciences, 100, 9096-9101.

The Royal Australasian College of Physicians (RACP) (2004). Children and the media: Advocating for the future [Online]. Retrieved 2 January, 2010 from http://www.racp.edu.au/page/ health-policy-andadvocacy/ paediatrics-and-child-health.

Wake, M., Hesketh, K., \& Waters, E. (2003). Television, computer use and body mass index in Australian primary school children. Journal of Paediatrics and Child Health, 39(2), 130-134.

Wallen, N., \& Fraenkel, J. (2001). Educational research: A guide to the process (2nd edn). Mahwah, New Jersey: Lawrence Erlbaum.

Wosje, K., Khoury, M., Clayton, R., Copeland, K., Kalkwarf, H., \& Daniels, S. (2009). Adiposity and TV viewing are related to less bone accrual in young children. The Journal of Pediatrics, 154(1), 79-85.

Young Media Australia (2003). Effects of the media from a child development perspective [Brochure]. South Australia: Young Media Australia.

Young Media Australia (2007). Overview of the effects of violence in the media. Retrieved 2 March, 2010 from http:// www.youngmedia.org.au/pdf/fact_sheets/02_01_overview_ violence.pdf.

Zentner, M., \& Eerola, T. (2010). Rhythmic engagement with music in infancy. Proceedings of the National Academy of Sciences [Online]. Retrieved 26 April, 2010 from http://www. pnas.org/content/107/13/5768. 